\title{
Factors Influencing Adoption Of Double-Rowplanting System Ofhybrid Corn On Dry Land In Pringgabaya, East Lombok, West Nusa Tenggara Province
}

\author{
Sudirman \\ Student at Dry Land Resource Management of Postgraduate Program, \\ Agricultural Faculty, Mataram University \\ IGL Parta Tanaya \\ Lecturer at Dry Land Resource Management of Postgraduate Program, \\ Agricultural Faculty, Mataram University \\ Tajidan Mahsunin \\ Lecturer at Dry Land Resource Management of Postgraduate Program, \\ Agricultural Faculty, Mataram University
}

\begin{abstract}
This research aimed to (1) know achievement level ofdouble-row planting system adoption of hybrid corn on dry land in Pringgabaya of East Lombok regency, (2) know the influence of internal and external factors both simultaneously and partially onthe adoption of double-row planting system of hybrid corn on dry land in Pringgabaya of East Lombok Regency.Unit of analysis in this study is farmers who implement the Specific Effort Program (UPSUS) of Hybrid corn Development in Pringgabaya of East Lombok Regency in 2017s. There was three villages determined by "purposive samplingmethode";North Pringgabaya, Labuhan Lombok, and Gunung Malang. Data obtained were analyzed by using descriptive methods and multiple linear regressions, with the following results: (1) The adoption of double-row planting system of hybrid corn is still in low level achievement (Adoption of $<50 \%$ ); there are only $26 \%$ of respondents are adopting the double-row planting system of hybrid corn. (2) Simultaneous test shows that the ten independent variables significantly influence the achievement level of the system adoption (p-value; $0,000<\alpha ; 0,05)$. (3) In the partial test, it was found that there are 6 (six) independent variables that significantly influence (p-value $<0,05$ ) the achievement of the innovation adoption; (1) education level (X2), (2) attendance frequency in counseling (X6), (3) level of risk-taking (X7), (4) ease/ trialability (X8), (5) compatibility (X9), and (6) communication (X10), while the other 4 independent variables do not give significant effect on the achievement level of the innovation adoption (p-value> 0,05); (1) age (X1), (2) number of family worker (X3), (3) experience of planting corn (X4) and (4) cultivated area (X5).
\end{abstract}

Keywords: Adoption, Double-row Planting System, hybrid corn.

\section{OVERVIEW}

Corn (Zea mays L.) is a food commodity which has important and strategic role in national development. The demand for maize continues to increase in line to population growth, as a result of increase of food demand, consumption of animal protein and energy. Considering the important functions and roles of the maize, the Government seeks to realize maize selfsufficiency by increasing corn production, one of which is through increasing cropping index and plant population through a double-row planting system. The Double-row planting system is a result of research and study, but has not been widely used by farmers. This is caused by several factors, both internal factors of the farmers themselves and external factors. According to data released in 2016s, the double-row planting system in East Lombok regency is slightly 
adopted; around 16,537.71 Ha of the total planted area of 26,863 ha or about $32.95 \%$ (BP4K East Lombok District, 2016). Furthermore, in accordance with the results of Bulu'sresearch (2009), it was found that corn planting innovation has been generated more through research and study, but has not been widely used by farmers.

Based on the description, this researchaimed to(1) know the achievement level of the adoption of double-row planting system of hybrid corn on dry land in Pringgabaya of East Lombok Regency, and (2) know the influence of internal and external factors both simultaneously and partially on the adoption of double-row planting system of hybrid corn on dry land in Pringgabaya District of East Lombok regency.

\section{METHODOLOGY}

Determination of location in this study was done intentionally (purposive sampling method), and the area chosenwas Pringgabaya District East Lombok Regency West Nusa Tenggara Province. There was determined three villages by "purposive sampling";North Pringgabaya, Labuhan Lombok, and Gunung Malang. This is in consideration that farmer groups in this 3 (three) Villages are implementing the Specific Effort Program (UPSUS) of Hybrid corn Development in 2017s. Determination of sample size in this study was taken using Slovin formula (Umar, 2000) and the result was 73 Respondents. The type of data in this study is qualitative and quantitative data.Qualitative data is data obtained, but not in numberform, while quantitative data is data in the form of numbers. Data sources are primary data and secondary data.

\section{DATA ANALYSIS}

To find out the achievement level of the innovation adoption,the study analysis was done by using descriptive analysis, meanwhile, to know the influence of internal and external factors both simultaneously and partially,it was done by using multiple linear regression analysis, which is simultaneous test through F test and partial test through test $t$. Statistics software used is SPFS 16.0.

\section{RESULTS AND DISCUSSION}

Achievement of the adoption was classified in 5 achievement levels;score of 1 for awareness, score of 2 for interest stage, score of 3 for evaluation stage, score of 4 for reaching trial stage and score of 5 for the adoption stage.

In this study, the adoption stage of the respondents was not done in sequence. This does not mean that the stages need to be followed generally by all respondents in taking the decision to adopt the double-row planting system. It can be understood, because each respondent has their own ability in implementing the double-row planting system, so the achievement level of the adoption can be categorized based on the cumulative number of farmers which is calculated from the awareness, interest, evaluation, trial, and adoption stage. The distribution of respondents' adoption level is presented in Table 1, as follows:

Table 1. The distribution of respondents' level in adopting the double-row planting system.

\begin{tabular}{llccc}
\hline No & Adoption level & Score & Cumulative number & Percentage Cumulative (\%) \\
\hline 1 & Adoption & 5 & 19 & 26,0 \\
2 & Trial & 4 & 44 & 60,3 \\
3 & Evaluation & 3 & 66 & 90,4 \\
4 & Interest & 2 & 72 & 98,6 \\
5 & Awareness & 1 & 73 & 100,0 \\
\hline
\end{tabular}

Source: Primary Data Processed 
Table 1 shows that all 73 respondent farmers (100\%) have reached the awareness stage. This means that all the respondent farmers know the double-row planting system, but still in general information, not in how to do the system.

Of the 73 respondents (100\%) who have reached the awareness stage, only 72 respondents $(98.2 \%)$ reach the interest stage. This means that most of them are interested in implementing the double-row planting system. This can also be seen that respondents have started to study in detail about the system of planting by collecting information from various parties, whether from print media, electronic media, social media (internet) and from surroundings such as neighbors, friends, local extension workers and other agricultural officers.

Of the 72 respondents (98.2\%) who reached the interest stage, only 66 respondents (90.4\%) have reached the evaluation stage, meaning that most of the respondent farmers have done good / bad evaluation on benefits and economic value of the planting system.

Of the 66 respondents (90.4\%) who reached the evaluation stage, only 44 respondents $(60.3 \%)$ continued to the trial stage, meaning that most of the respondentshave tried the system although in small scale ranged from 10 to 20 aces. There are also farmers tried jointly in one group on the area of 1 ha.

Of the 44 respondents (60.3\%) who reached the trial stage, only 19 respondents (26\%) continued to adoption, meaning that a few respondents decided to apply the system because they considered the system is profitable in a wide scale.

Thus, the adoption of the double-row planting system of hybrid corn in Pringgbaya sub-district of East Lombok is still in low achievement (reaching $<50 \%$ adoption stage), of which only $26 \%$ of respondents have adopted the planting system. Continuous adoption of the planting system is linked to the mindset in an effort to increase production and productivity.This is in line with study result presented by Tajidan et al. (2013) showing that if technology is adopted continuously in recommended inputs which overcomes problems of farmers, food production, supply and carrying capacity increases, supply chain management can be achieved.

Meanwhile, to find out the inequality, method used was Gini index withthe results visualized in Lorenz curve. Based on the calculation, value of Gini index generatedwas 0.1418, which means there is inequality distribution of the adoption at low rate levels (Appendix 6). According to Oshima (1976) in Sugiyarto, et al (2015), GR $<0.4$ belongs to the category of low inequality, $0.4 \leq \mathrm{GR} \leq 0.5$ is in moderate inequality and GR $>0.5$ is in high inequality. This inequality occurs due to factor of the farmers as a candidate adopter, the characteristic of the system, communication systems used, andsurrounding environmental factors. In a curve, the Gini index value of 0.1418 is illustrated in Figure 1, as follows: 


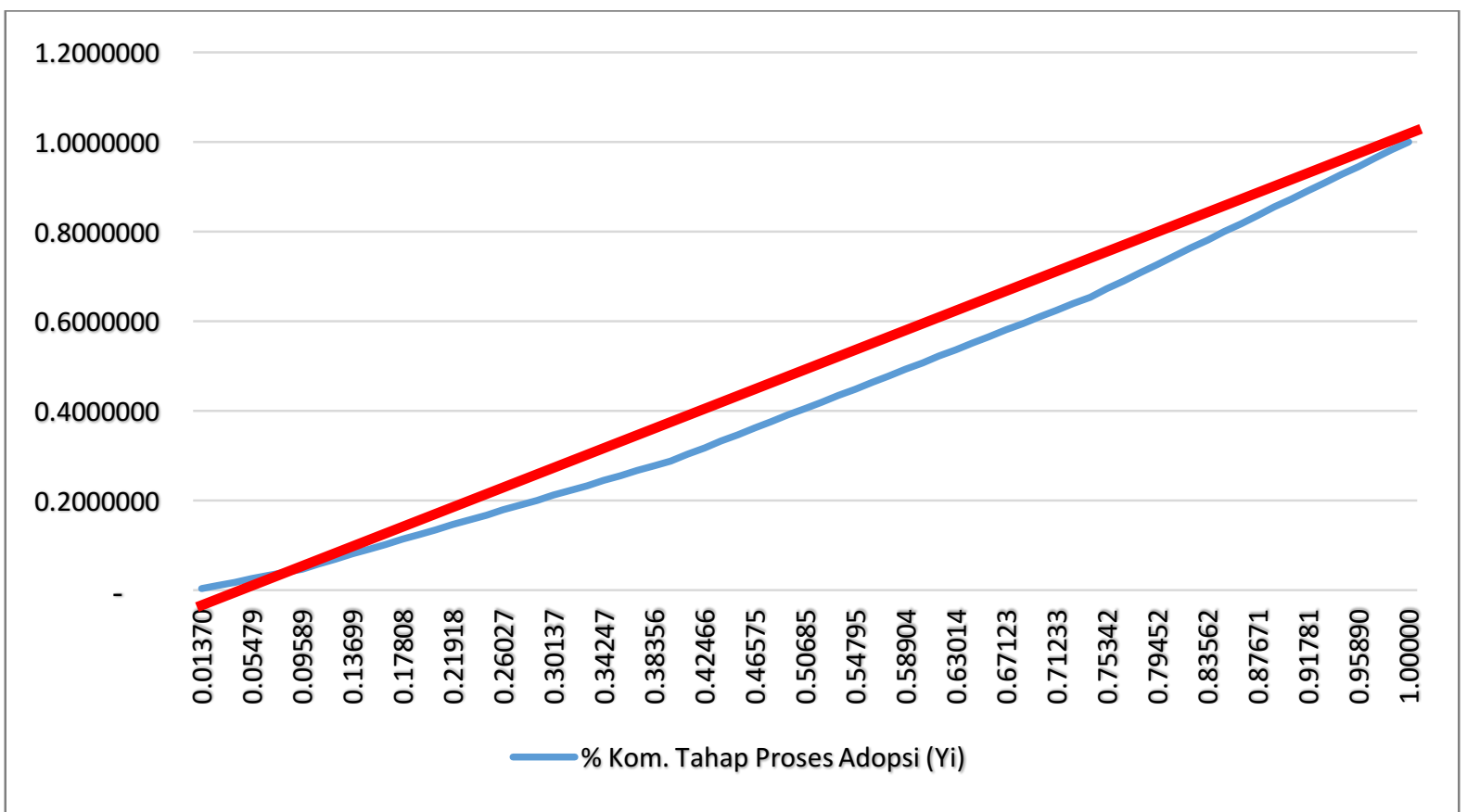

Figure 1. Lorenz Curve Distribution of Adoption of the double-row planting system in Pringgabaya, East Lombok (Source: Primary Data Processed in Appendix 6).

Figure 1 shows that the red diagonal line is the evenness line, indicating that in that position the adoption of the system is equally distributed to all the respondent farmers. In the Gini index, the fairness hasGini index value of 0 . The further the Lorenz curve from the evenness line shows an increasing inequality. Perfect inequality occurs when the Gini index value is worth 1. Low inequality indicates that a small percentage of farmers are reaching the adoption stage or only a small percentage remains conscious among other farmers. Inequality is due to existence of obstacles such as the delay of subsidized seeds and fertilizers.

\section{Estimation of Research Model Factors Affecting the Adoption}

Estimation to know the effect of free variable in the form of age (X1), education level (X2), number of family worker (X3), corn farming experience (X4), cultivated area (X5), attendance frequency (X6), risk taken (X7), level of ease/trialability (X8), compatibility (X9), and communication (X10), with dependent variable is achievement of the adoption (Y). it is analyzed by using multiple linear regression model. The result of analyzedis presented in Table 2, as follow: 
Tabel2.Estimation result of factor affecting the adoption of the double-row planting system in Pringgabaya, East Lombok.

\begin{tabular}{llcccccc}
\hline No & \multicolumn{1}{c}{ Variable } & Coef. & $\begin{array}{c}\text { Std. } \\
\text { error }\end{array}$ & Beta & t & p-value & Sig. \\
\hline 1 & (Constant) & 0,188 & 0,242 & & 0,775 & 0,441 & Non significant \\
2 & Age (X1) & 0,010 & 0,008 & 0,069 & 1,184 & 0,241 & Non significant \\
3 & Education level (X2) & 0,153 & 0,028 & 0,389 & 5,487 & 0,000 & Significant \\
4 & number of family worker (X3) & $-0,037$ & 0,021 & $-0,050$ & $-1,761$ & 0,083 & Non significant \\
5 & corn farming experience (X4) & $-0,002$ & 0,008 & $-0,011$ & $-0,202$ & 0,840 & Non significant \\
6 & cultivated area (X5) & 0,000 & 0,002 & 0,004 & 0,119 & 0,906 & Non significant \\
7 & attendance frequency (X6) & 0,140 & 0,045 & 0,186 & 3,083 & 0,003 & Significant \\
8 & Risk-taking (X7) & 0,085 & 0,038 & 0,091 & 2,209 & 0,031 & Significant \\
9 & level of ease/trialability(X8) & 0,099 & 0,038 & 0,106 & 2,623 & 0,011 & Significant \\
10 & compatibility (X9) & 0,158 & 0,046 & 0,173 & 3,428 & 0,001 & Significant \\
11 & communication (X10) & 0,126 & 0,059 & 0,094 & 2,132 & 0,037 & Significant \\
\hline
\end{tabular}

Source: Appendix 1.

Note: Significant in $\alpha=0,05$ (one tailed) with t Table $=1,669$

Based on the table 2 , the research estimation model is:

$\hat{\mathrm{Y}}=0,188+0,010 \mathrm{X} 1+0,153 \mathrm{X} 2-0,037 \mathrm{X} 3-0,002 \mathrm{X} 4+0,000 \mathrm{X} 5+0,140 \mathrm{X} 6+0,085 \mathrm{X} 7+0,099 \mathrm{X} 8+$ $0,158 \times 9+0,126 \times 10$.

\section{Model Conformity Test}

Before performing the hypothesis of simultaneous influence or partial influence, firstly,the test done was the suitability model (Goodness of Fit) or $\mathrm{R}^{2}$ test. As the result of the estimation (attached) found the correlation coefficient (R) and coefficient of determination $\left(R^{2}\right)$ as shown in Table 3, as follows:

Table3.Goodness test

\begin{tabular}{cccc}
\hline$R$ & $R$ Square & Adjusted R Square & Std. Error of the Estimate \\
\hline $0,978 \mathrm{a}$ & 0,957 & 0,95 & 0,21956 \\
\hline
\end{tabular}

Source: Appendix 1.

Table 3 shows that the value of R-Square $\left(R^{2}\right)$ is 0.957 which means that independent variables such as age (X1), education level (X2), number of family labor (X3), corn farming experience (X4), cultivated area (X5), the frequency of attendance in counseling (X6), the level of risktaking (X7), the ease level(X8), the compatibility level (X9) and the communication (X10) can explain the achievement of adoption (Y) equal to 95,7 percent. While the rest of 4.3 percent explained by other variables which are not included in this research model. In other words, the coefficient of determination of 95.7 percent has the meaning that the diversity in the dependent variable (Y) can be explained by the 10 independent variables (X).

\section{Simultaneous and Partial Test a. Simultaneous Test}

The simultaneous test is performed in order to test the significance of the independent variables in influencing the dependent variable. The test is done by comparing F-Table value with $\mathrm{F}$. The degree of freedom in the $\mathrm{F}$ test is $\mathrm{v} 1=(\mathrm{k}-1)=(11-1=10)$ and $\mathrm{v} 2=(\mathrm{n}-\mathrm{k})=(73-11=$ $62)$, with $\alpha=0.05$, the F-table generated is 1.99 . 
Table 4. Table Analysis of Variants (ANOVA).

\begin{tabular}{lccccc}
\hline \multicolumn{1}{c}{ Model } & Sum of Squares & $d f$ & Mean Square & F & P-value (Sig) \\
\hline Regression & 66,573 & 10 & 6,657 & 138,101 & $0,000^{\underline{a}}$ \\
Residual & 2,989 & 62 & 0,048 & & \\
Total & 69,562 & 72 & & & \\
\hline
\end{tabular}

Source: Appendix 1.

Note:

Significant at $\alpha=0.05$ (F Table (ANOVA) $=1.99$ ).

Based on Table 3, it is found that $\mathrm{F}$ value $=138,101>\mathrm{F}$ Table $=1.99$ andP-value $=0,000<\alpha=0.05$. This means that independent variables such as age (X1), education level (X2), number of family labor (X3), corn farming experience (X4), cultivated area (X5), the frequency of attendance in counseling (X6), the level of risk-taking (X7), the ease level(X8), the compatibility level (X9) and the communication (X10), simultaneously have a significant effect on achievement of the planting system adoption on dry land in Pringgabaya, East Lombok. Based on this result, the null hypothesis $\left(\mathrm{H}_{0}\right)$ is rejected, while $\mathrm{H}_{1}$ is accepted. Due to the acceptance of $\mathrm{H}_{1}$, it can be concluded that all independent variables simultaneously gave significant effect on the dependent variable.

\section{b. Partial Test}

Different from the Simultaneous test comparing F and F-Table, Partial test (individual) is done by comparing tand t-table value. It can also be seen based on the value of significance ( $p$-value) on prediction results (attached).

With the number of sample $(\mathrm{n})=73$, the number independent variable $=10$ (Koutsoyiannis (1981) in Desky (2007) explains that the magnitude $\mathrm{k}$ is the independent variable including the constants, thus $\mathrm{k}=11$ ), Degree of Freedom $(\mathrm{df})=62$, t-Table generated on one tailed test; $\alpha$ $=0.05$ is worth $1.668(\mathbf{t}-$ table $=1,668)$.

Based on the results shown in Table 2, there are 6 independent variables which have significant effect ( $p$-value $<0.05$ ) on the achievement of the adoption (Y); the education level (X2), the frequency of attendance in counseling (X6), risk-taking (X7), ease level of the system (X8), compatibility (X9) and communication (X10). In detail, itis described as follows:

\section{Education level.}

The duration of formal education of farmers or higher education provides a higher adoption achievement. The coefficient of variables marked positive, meaning that the farmer's education increases is in line with the increase of the adoption achievement. This phenomenon can be explained because the adoption of technology is strongly influenced by the perception of farmers on the technology itself. The formation of one's perception is influenced by the level of formal education (Aswanto, 2002, and Stoner and Freeman, 1989 in Sudjarmoko, 2009).

\section{Frequency of attendance in counseling}

The coefficient of the variable is marked positive, meaning that the increase of attendance frequency in counseling, the adoption achievement will increase. Presence in counseling is very important to improvefarmers' knowledge (cognitive), skills (psychomotor) and attitudes (affective) and very influential on technology adoption. This is in accordance with the results of Harinta's research (2010) claimed that the factors of participation rate in farming families, interpersonal communication and innovation information have significant effect ( $p$-value $<0.01$ ) on adoption rate of agricultural innovation. It is also in line with Mardikanto'sopinion 
(1996) in Harinta (2010) stated that community members who like to join people outside of their own social system are generally more innovative than those who only make personal contact with local community.

\section{Level of ease / Trialability}

It can be said that the higher the level of an innovation triads (X8) of will increase the achievement of innovation adoption (Y). Trial is the equivalence of the convenience, meaning that the easier a new technology to try, the faster the process of adoption of innovation. The high level of ease is one of the properties of the double-row planting system, which is very easy to try out by the farmers. This is in line with the results of Harinta's research (2010), claiming that the innovation characteristic or trialability (X1.4) providesp $=0,000<\alpha=0,05$. This means that the variable (X1.4) have a significant relation with the adoption variables of agricultural innovation (Y).

\section{Degree of compatibility}

The higher level of innovation compatibility (X9) will increase the achievement of innovation adoption (Y). The compatibility is one of the characteristics / characteristics in accordance with the existing technology because this innovation system (double-row planting system) is a further development of existing technology. This is in line with the results of Harinta'sresearch (2010), describing that the compatibility level (X1.2) provides $p$-value $=0,000<\alpha=0,05$, so the variable has a significant relationship with agricultural innovation adoption variables (Y).

\section{Levelof risk-taking}

The higher level of embracingrisk-taking (X7) will increase the achievement of innovation adoption (Y).Risk-taking is one of the characteristic of the respondents.

The result of this research is in line with result of Harinta'sresearch (2010), saying that the characteristic of user (X2) gives $p=0,000<\alpha=0,05$. This means that the variable of user characteristic (X2) give a significant effect to the adoption of agriculture innovation (Y).

\section{Communication channels}

The more personal the communication channel used (X10), the more achievement of adoption (Y) increased. This is supported by the research result of Harinta (2010), the communication channel/media used (X4) provides $p$-value $<0,05$, so it can be concluded that there is significant effects between the variables of communication channel / media used (X4) with variables of innovation adoption (Y).

Furthermore, Karyadi (2016) suggested that the determination of communication channels should be done regarding to the communication objectives and communication targets, so that an effective intrapersonal channels (individual) in can be positively give effect on innovation.

The 6 variables $(\mathrm{X})$ described are give a significant effect on the adoption achievement (Y), while the other 4 independent variables (age (X1), number of family worker (X3), experience of corn farming ( X4) and cultivated area (X5)) provide p-value $>0,05$. This means that the 4 variables $(\mathrm{X})$ do not give significant effect on the adoption achievement variable (Y)

\section{CONCLUSIONS AND RECOMMENDATIONS}

Based on the result of the research, it can be concluded that the adoption of the double-row planting system of hybrid corn in Pringgabaya of East Lombok Regency is still in low level achievement, of which only $26 \%$ of respondents reach the adoption of the innovation. 
Simultaneous test shows that together all the ten independent variables give a significant effect on the achievement level of innovation adoption ( $p$-value; $0,000<\alpha ; 0,05$ ).

In the partial test,it was found that there are 6 (six) independent variables that significantly influence ( $p$-value $<0,05$ ) the achievement of the innovation adoption; (1) education level (X2), (2) attendance frequency in counseling (X6), (3) level of risk-taking (X7), (4) ease/ trialability (X8), (5) compatibility (X9), and (6) communication (X10), while the other 4 independent variables do not give significant effect on the achievement level of the innovation adoption ( $p$ value> 0,05); (1) age (X1), (2) number of familyworker (X3), (3) experience of planting corn (X4)and (4) cultivated area (X5).

Based on the study results, there are some recommendations, namely:

1. Educational variable significantly influence the achievement level of the adoption, thus the adult learning process (andragogy) through counseling should be improved in order to increase the motivation and confidence of farmers.

2. Number of attendance in counseling has significant influence to achievement level of adoption, thus it needs to improve the performance of councilor at field through approach of frequency of visit to farmer / farmer group.

3. Channels of communication give significant effect on the adoption. So, it is recommended that the extension system with the method of Training and Visits to be enhanced.

4. The trialability and compatibility of the innovations also significantly affect the achievement level of the adoption. It would be a consideration of the government and the related parties in offering technology to implementthe program of Specific Effort (UPSUS) of hybrid corn development.

\section{DAFTAR PUSTAKA}

BP4K Kabupaten Lombok Timur. 2016. Rilis Data UpayaKhususPadi, JagungdanKedele (UpsusPajale). BadanPelaksanaPenyuluhanPertanianPerikanandanKehutananKabupaten Lombok Timur. Selong.

Bulu Y.G, Hariadi S.S, Herianto A.S, danMudiyono. 2009. Pengaruh Modal SosialdanKeterdedahanImformasiInovasiTerhadap Tingkat AdopsiInovasiJagung di Kabupaten Lombok Timur Nusa Tenggara Barat. BalaiPengkajianTeknologiPertanian Nusa Tenggara Barat. Mataram.

Desky, S. 2007. AnalisisFaktor-faktor yang MempengaruhiProduksiPadi di Kabupaten Aceh Tenggara. Tesis. Universitas Sumatera Utara. Medan.

Harinta, Y.W. 2010. Faktor-Faktor yang MempengaruhiKecepatanAdopsiInovasiPertanian di KalanganPetani Di KecamatanGatakKabupatenSukoharjo. Tesis. Program PascaSarjanaUniversitasSebelasMaret. Surakarta.

Karyadi W.L. 2016. PenyuluhandanKomunikasiPertanian. PustakaBangsa. Mataram.

Sudjarmoko, B. 2009. FaktorPenentuAdopsiTeknologiVanili di Jawa Barat. BalaiPenelitianTanamanRempahdan Aneka TanamanIndustri. BuletinRistri Vol. 1 (4) 2009.

Sugiyarto, Mulyo. J.H danSeleky, R.N. 2015. KemiskinandanKetimpanganPendapatanRumahTangga di KabupatenBojonegoro. JurnalAgro Ekonomi Vol. 26/No. 2. Desember 2015.

Tajidan, Setiawan. B, Mustadjab.M.M and Muhaimin, A.W. 2013. The Strategy of Business Process Integration and Competitive Advantage in a Supply Chain Collaboration with the Outcome Corn Farmers' Welfare in West Nusa Tenggara Province - Indonesia. International Journal of Science and Research (IJSR) ISSN (Online): 2319-7064. Volume 2 Issue 11, November 2013.

Umar, H. 2000. MetodePenelitian. PT. Raja GrafindoPersada. Jakarta. 